Finanse, Rynki Finansowe, Ubezpieczenia nr 5/2017 (89), cz. 2

\title{
Success and failures of crowdfunded projects in Poland
}

\author{
Joanna Adamska-Mieruszewska, Urszula Mrzygłód, \\ Marcin Skurczyński*
}

\begin{abstract}
Summary: Objective - In recent years the crowdfunding platforms have gained importance as a intermediation vehicle which facilitates revealing project's unique character to a wide audience, and simultaneously attracting potential investors. The number of projects financed through Polish crowdfunding platforms raises the question about the causes of successes and failures in engaging investors. The main goal of the paper is to examine major characteristics of the projects offered on the platform PolakPotrafi.pl, with special emphasis on the potential drivers of success and failures.

Methodology - In the study descriptive statistical methods have been employed on a unique dataset of 1850 projects published on the platform PolakPotrafi.pl in years 2011-2016.

Result-Based on the statistical analysis, the most important trends in crowdfunding financing as well as the characteristics of projects have been identified.

Originality/value - Data collection has been conducted automatically based on the authors' original script written in Python language.
\end{abstract}

Keywords: crowdfunding, success determinants, empirical study

\section{Introduction}

Brilliant ideas for business, product or events can sometimes emerge in one's mind effortlessly, however implementing them into practice requires a number of tactical operations to be pursued. First, one must become aware of the essential character of the novel idea. Thus, in this phase one has to conduct preliminary market research which simultaneously contributes to acquisition of knowledge about the potential customers, competitors and risks. Altogether at the end of this early stage one must develop the basic idea for business as well as define a niche on the market. Second, one has to provide a detailed, and solid business plan and finally, one must secure sufficient financial resources to establish a business or launch a project. While it is beyond the scope of this paper to discuss all the problems encountered in each of the phases mentioned above, the sources of funding for creative ideas as well start-ups warrant attention here.

* mgr Joanna Adamska-Mieruszewska, Instytut Handlu Zagranicznego, e-mail: ekojam@ug.edu.pl; dr Urszula Mrzygłód, Instytut Handlu Zagranicznego, e-mail: ekoum@ug.edu.pl; dr Marcin Skurczyński, Instytut Handlu Zagranicznego,e-mail: marcin.skurczynski@gmail.com. 
Entrepreneurs seem to have a broad range of internal and external sources to finance business projects e.g. retained earnings, loans, credits, leasing, shares, bonds. However, projects that entail higher levels of risk are less desirable for capital providers. Indeed, traditional sources of financing favor traditional projects, also in terms of risk. Therefore as a business beginner, one often needs to utilize own as well as family financial reserves or augment the level of personal debt. Among the potential financial sources for start-ups are the so-called business angels and crowd investors. Whereas funds from the latter group are becoming more available in recent years, the number of former potential investors from is rather low in many countries. Similarly the level of risk capital i.e. venture capital and private equity is below needs. Essentially, for many novel ideas and business start-ups securing financial resources becomes a considerable obstacle.

The existing market gap in start-ups funding has led to the growing interest in crowd financing. Not only many crowdfunding platforms are starting to operate across countries, but also this form of financing gained increased attention from researchers as well as policy makers. In particular European Commission is interested in the development of the crossborder crowdfunding business (European Commission, 2016). The potential of this form of financing has been also recognized by AFME in the recent report on the risk financing (AFME, 2016).

Similarly to other modern economy innovations the crowdfunding is a dynamic form of alternative financing which is difficult to define because of its' varied business models. Generally, crowdfunding can be explained as an open announcement to a wide public (community) to raise funds for a particular project (AFME, 2016). Belleflamme et al. (2014) accentuate that funds are raised "either in the form of donations or in exchange for the future product or some form of reward to support initiatives for specific purposes". Further discussion on the definition, and typology of crowd financing can be found in Belleflamme et al. (2015); Mollick (2014); Šoltés, Štofa (2016); Kozioł-Nadolna (2015); Dziuba (2015), Cichy, Gradoń (2016); Wieczerzycki (2014); Adamska-Mieruszewska, Mrzygłód (2014).

A growing body of literature focuses on the projects' properties that lead to obtain the required level of funding. It is worth mentioning that many crowdfunding platforms operate in an "all or nothing" model. This means that a project' owner receives money only if the collected amount reaches or exceeds the initial target. Therefore exploring the drivers of projects' attractiveness to the crowd investors becomes simultaneously a practical issue.

Despite this strong interest in the success factors among international researchers apparently vast of the empirical studies are conducted on the basis of the US data. This can be attributed to a longer history, more advanced crowdfunding market in comparison to other countries as well as to an appealing success of the US Kickstarter platform. In empirical research less attention is paid to other countries which also experience dynamic growth of this business area. Therefore the main goal of this paper is to examine major characteristics of the projects announced on the Polish crowdfunding platform PolakPotrafi.pl. Based on 
a unique dataset of 1850 projects we conduct an exploratory study with special emphasis on the potential drivers of the projects' success and failures.

The remainder of the paper is organized as follows. The concise literature review regarding the drivers of the projects' success and failure is presented in the next section, whereas research design is discussed in section 2. Next sections cover the statistical characteristics of the obtained data (section 3 ) as well as the indication of the potential drivers of success (section 4). Conclusions and implications for further research are presented in the last section.

\section{Literature review}

As crowdfunding is a form of raising funds through an open call on the Internet, the distance-related frictions should not be as significant as in, for example, venture capital or business angels funding. This contrast with traditional theories assuming there is a geographic proximity between investors and entrepreneurs due to, inter alia, distance-sensitive costs connected with providing input or gathering information. Agrawal et. al. (2011) examined the geographic origin of investors in 4,712 crowdfunding projects presented on platform for musicians. The authors observed that the distance between investor and entrepreneur was on average 3,000 miles. Thus, they highlighted that crowdfunding platforms tend to reduce the distance barrier in funding projects.

In their further research Agrawal et. al. (2015) indicate that crowdfunding platforms have three attributes that facilitate distance-related frictions to diminish. That is: standardized layout that enables easier search for projects; relatively small values of individual investment which do not trigger the one's need of control, and immediate information about others investors behaviors.

By comparison on the basis of 48,034 projects from Kickstarter Mollick (2014) confirms the uneven geographical distribution of crowdfunding projects in United States. Moreover Mollick (2014) postulates clustering patterns among US cities and individual categories of crowdfunding projects, namely music, film, technology. Indeed Mollick reports that the distribution of projects coming from San Francisco reveals larger share of projects in field of technology, games and design.

Furthermore Mollick confirms other important drivers of success, namely shorter period of money collection, larger size of the founders' social network, higher level of the founders' initiative in providing updates to projects, videos, and lower level of the spelling mistakes in projects presentation. On the contrary, Cordova et al. (2015) argue that expanding the project duration increases the chances of raising the necessary amount. In their study the authors concentrate solely on the technology start-ups by employing data collected from 4 platforms: Kickstarter, Ulule, Eppela, Indiegogo. Additionally Cordova et al. (2015) confirm that increasing the pledged amount reduces the chances for projects' success. 
Again Kickstarter has been a source of data for the study conducted by Koch and Siering (2015). Having smaller sample size at their disposal (1,000 projects) the authors investigate the drivers of projects success and confirm the significance of the pledged amount and media richness. Contrary to Mollick (2014) in their study Koch and Siering argue that the number of friends on social platform as well as the length of the project duration has no impact on the success probability. In addition to previous studies Koch and Siering evaluate the significance of the founders' previous experience with crowdfunding platforms. The study reveals that the chances to obtain the required target amount are higher if the project owner also financially supports other proposals announced on the crowdfunding platform.

Finally, it is worth to mention the study based on the dataset of 740 projects from Switzerland conducted by Beier and Wagner (2015). The authors similarly to Mollick confirm that frequency of the project updates reinforces the chances to obtaining the required level of funds on the crowdfunding platform. Furthermore, Beier and Wagner (2015) argue that applying videos enhances the level of media richness in communication with crowd investors and thus contributes to the projects' success.

\section{Research design}

In order to explore the success factors of the Polish crowdfunded projects we extracted data from the one of the largest platforms operating in Poland, namely Polakpotrafi.pl. Established in March 2011, this platform uses donation-based crowdfunding offering rewards. Ever since its beginnings, the platform claims to have helped to obtain over 17 million PLN worth of funding for almost 3,000 projects. Similarly to many other crowdfunding platforms Polakpotrafi.pl operates in the 'all or nothing" model.

Database was built based on a procedure that employed a programme written in the Python language. The data was collected between 20 August and 2 September 2016 and refers to projects submitted to the platform from 2011 until 2 September 2016. The object of the survey was to collect information on current (on-going) and historical (completed) projects, including also about ones which were unsuccessful, i.e. ones that failed to raise the required funding. Data on failed projects was collected with the assumption that investors supporting successful projects also declared their support in the past for projects which eventually failed to obtain funding. The most important characteristics were recorded for each project.

Initially, 1,260 websites were identified, describing on-going or successfully completed projects. On that basis, a list of 17,098 unique profiles was compiled detailing supporter data. The assumption that those who supported the current projects also supported other projects in the past proved right. Identified users were found to support 2,380 projects in total. This data was used to build a list of all supporters, including 96,878 user profiles.

The compiled lists and collected user data underwent preliminary analysis. The analysis included valid websites of actually existing projects and test profiles on the platform. 
The project websites offered complete and fully operational www services or incomplete/ incorrect information. Eventually, projects returning incomplete or incorrect information were eliminated and data was collected concerning 1,850 projects whose individual websites were identified in the analysis.

The results amassed in this way were processed using the SPSS package. As the first step, frequency analyses were carried out and statistical metrics taken.

A survey of the literature and data on crowdfunded projects submitted in 2011-2016, collected by methods described above from PolakPotrafi.pl allowed defining the following factors which may determine the success of a project, understood as raising the required amount. These factors will be analysed later.

- location (town) tied to the project,

- month of publication on the platform,

- media presence (number of mentions in the media),

- activity on the platform:

- number of project-related news items added by initiators,

- number of user comments on the project or its initiators.

\section{Projects characteristics}

The research focused on projects presented on the PolakPotrafi.pl platform from 2011 until the end of August 2016. In total, 1,850 projects were completed, of which 23 in 2011, 88 in 2012, 308 in 2013, 527 in 2014, 550 in 2015 and 354 in 2016. The sample also included all projects ending with the grant of funding. Their number has been steadily rising since the platform was first launched. 51,7\% of the projects (957) were successful, while the remaining 893 did not receive funding.

The projects presented on PolakPotrafi.pl are allocated to categories set up by the platform creators. Each project is assigned to a category which forms the main sorting criterion. This means that each project can be assigned to only one category. In the period under investigation, the most projects (15\% of all undertakings) appeared in the category Music, while a further $10 \%$ in the categories Books and Video/film, respectively. The following categories accounted for the smallest percentage: Comics, Fashion (each around 0.5\%), Food, Dance (each around 1\%). The following were the most popular categories: Music - this category featured the highest fail rate (180 as compared to 96 successful projects). A reverse tendency emerged for projects in the category Technology (out of a total of 87 projects, only 26 proved to be failures).

As data in Table 1 indicates the success rate varies in different project categories, starting from 18,1 in Fashion to 65.2 in Music. It worth to note that in twelve out of 20 categories success rate exceed $50 \%$. 
Table 1

Basic characteristics of the data sample

\begin{tabular}{lclrcrr}
\hline \multirow{2}{*}{ Category } & \multirow{2}{*}{ No. of projects } & \multicolumn{2}{l}{$\begin{array}{l}\text { Success rate } \\
(\%)\end{array}$} & \multicolumn{2}{c}{ Target amount (PLN) } & \multicolumn{2}{c}{ Raised amount (PLN) } \\
\cline { 5 - 7 } & & mean & median & mean & median \\
\hline Design & 25 & 32.0 & 15,045 & 8,000 & 5,857 & 1,394 \\
Journalism & 24 & 50.0 & 10,578 & 5,750 & 8,323 & 2,495 \\
Education & 127 & 34.6 & 11,277 & 8,000 & 4,928 & 1,452 \\
Photography & 23 & 47.8 & 8,237 & 5,000 & 5,448 & 2,054 \\
Games & 40 & 30.0 & 7,597 & 5,900 & 7,973 & 1,425 \\
Other & 57 & 36.8 & 11,051 & 5,000 & 2,922 & 1,257 \\
Food & 18 & 50.0 & 21,492 & 8,397 & 7,128 & 3,070 \\
Comic books & 10 & 60.0 & 6,565 & 3,500 & 4,791 & 3,879 \\
Books & 193 & 51.3 & 8,972 & 6,000 & 6,317 & 2,224 \\
Fashion & 11 & 18.2 & 6,453 & 4,700 & 1,526 & 330 \\
Music & 276 & 65.2 & 8,744 & 6,000 & 6,705 & 4,795 \\
Travel & 182 & 54.9 & 7,766 & 5,000 & 4,914 & 3,044 \\
Community & 148 & 54.1 & 15,184 & 8,250 & 9,843 & 3,152 \\
Sport & 163 & 63.2 & 12,817 & 9,999 & 10,211 & 4,720 \\
Art & 55 & 45.5 & 13,785 & 5,000 & 3,629 & 1,596 \\
Dance & 20 & 65.0 & 7,430 & 5,350 & 4,975 & 4,347 \\
Theater & 59 & 62.7 & 6,006 & 5,000 & 4,164 & 2,763 \\
Technology & 87 & 29.9 & 18,406 & 9,500 & 5,086 & 668 \\
Video/film & 188 & 51.1 & 9,928 & 6,000 & 5,673 & 2,708 \\
Events & 144 & 50.7 & 6,904 & 4,950 & 3,375 & 1,430 \\
\hline
\end{tabular}

Source: own elaboration.

In Table 1 the mean and median levels of the target as well as raised amount are presented. Overall in each category the median level of target and raised amount is lower than the mean. This implies that we should concentrate on the median levels since there are significant outliers among the collected crowdfunded projects.

According to the crowdfunding philosophy, the initiator is obliged to declare a minimum amount - target amount, which must be raised for the project to be considered successful. The project owners require the highest amounts in categories Sport $(9,900)$, Technology $(9,500)$ and Food $(8,400)$. On the contrary the largest sums per project were raised in the categories Music $(4,795$ PLN), Sport $(4,720)$, and Dance $(4,347)$. The projects in the categories Fashion (330 PLN) and surprisingly Technology (668 PLN) obtain the lowest levels of funds. Thus, it seems that novel technological ideas submitted for financing are not attractive for crowd investors.

Raising funds is not complete when the stated minimum has been collected, but continues until the day designated as the deadline. In this way, it happens that funds raised exceed the target amount, especially in very attractive projects. The average surplus raised in the projects under investigation was 2,022 PLN, over 2,500 PLN in projects located in smaller 
towns and over 1,950 PLN in larger cities. The most - over 3,000 PLN in Warsaw and Łódź. In the case of failed projects, the shortfall was, on average, 11 thousand PLN.

\section{Selected success factors of crowdfunded projects presented on the platform PolakPotrafi.pl}

Each project description on Polakpotrafi.pl includes the most important information about the initiator (project owner), such as his/her name, location he/she is tied to (e.g. initiator's hometown or place where the project will be implemented). As the survey of the literature suggests, location factors essential for project's success.

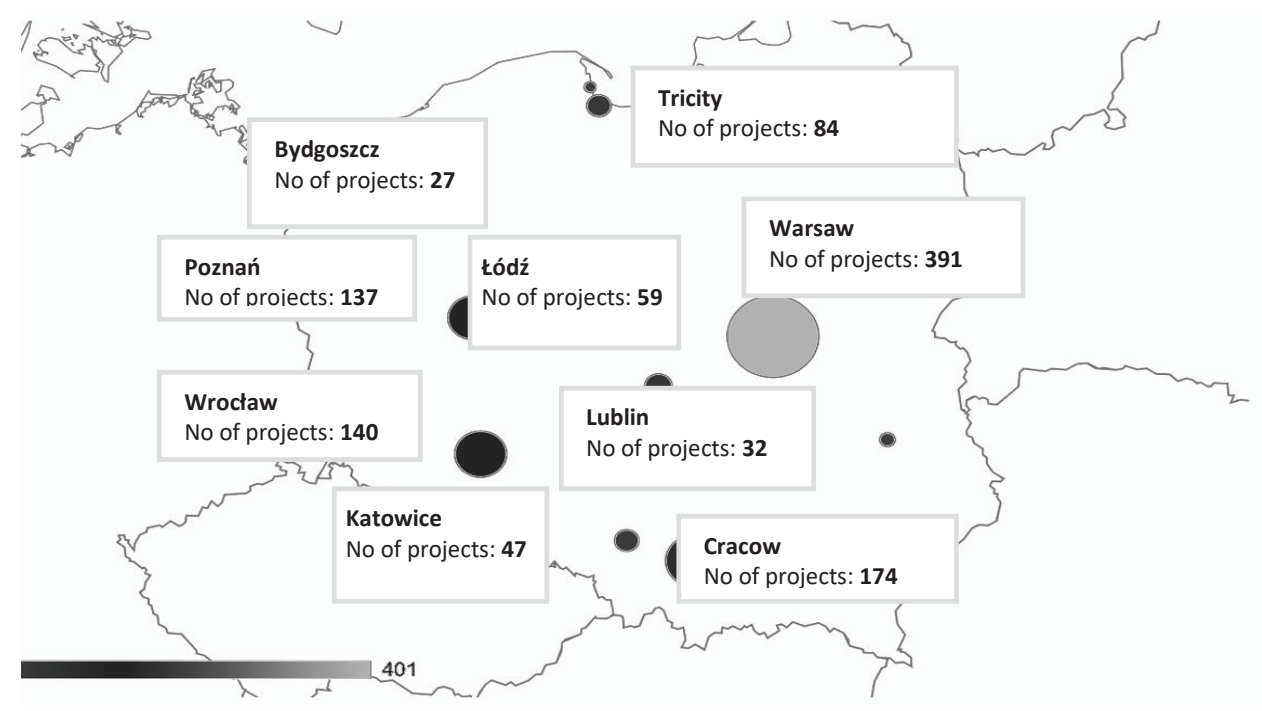

Figure 1. The number of crowdfunded projects and their location

Source: own elaboration.

Successful and unsuccessful projects were surveyed separately to measure the extent to which the project initiator's location determines the success of the project itself. The projects in these two groups were combined and allocated to two categories: big cities and other locations.

Out of the 1,850 projects under analysis, $60 \%$ were projects tied to one of the listed big cities. Most of them (401) were projects from Warsaw, then from Cracow (178), Wrocław (140) and Poznan (137) - Figure 1. In the sample, the average percentage of projects which did not receive funding equalled approximately $48 \%$. The average failure rate in the research period was $46 \%$ for large cities and $55 \%$ for other areas. The lowest rejection rate 
was noted in Cracow, Warsaw and Poznań, while the highest in Szczecin and Katowice (over $60 \%$ and over $50 \%$ respectively).

Table 2

The number of crowdfunded successful and unsuccessful projects and their location

\begin{tabular}{lcccl}
\hline Cities & No. of failures & No. of successes & $\begin{array}{l}\text { No. of projects } \\
\text { (in total) }\end{array}$ & $\begin{array}{l}\text { Share of failures in total number } \\
\text { of crowdfunded projects }(\%)\end{array}$ \\
\hline Warsaw & 169 & 222 & 391 & 43.22 \\
Katowice & 25 & 22 & 47 & 53.19 \\
Cracow & 64 & 110 & 174 & 36.78 \\
Łódź & 28 & 31 & 59 & 47.46 \\
Tricity & 38 & 46 & 84 & 45.24 \\
Poznań & 60 & 77 & 137 & 43.80 \\
Wrocław & 65 & 75 & 140 & 46.43 \\
Bydgoszcz & 13 & 14 & 27 & 48.15 \\
Szczecin & 12 & 7 & 19 & 63.16 \\
Lublin & 11 & 21 & 32 & 34.38 \\
Other locations & 408 & 332 & 740 & 55.14 \\
\hline Total & 893 & 957 & 1,850 & 48.27 \\
\hline
\end{tabular}

Source: own elaboration.

Another factor that may determine the potential success of the crowdfunded project is the month of the announcement. In the 2011-2016 sample, the largest number of projects were submitted from March to August. 193 projects were submitted in March, 171 in August and 235 in May, with the activity dropping sharply in September - only 108 projects. A similar tendency occurred in all the years under investigation. The number of projects increases in spring to reach its peak in May, and then drops gradually over the autumn and winter period (Figure 2). It is noteworthy that the average fund-raising time is around 40 days. This means that projects which begin in May, June or July finish in the summer, while those initiated in August are completed in autumn.

The largest fail rate (58\%) was observed in projects published in August and June (52\%), whereas the lowest in projects initiated in September (39\%), December (44\%) and February (45\%). At the same time, however, in September and December there was the lowest number of projects submitted for fundraising. Therefore, it may be supposed that projects submitted in these months were prepared more carefully and their initiators were more involved (active) on crowdfunding platforms. On the other hand, assuming that investors are generally active and will support projects more than once, fewer projects means less competition for supporter interest.

The nature of crowdfunded projects, especially the fact that they are available only on-line, makes the media, including particularly social media, a vital factor for their success. Media presence allows project initiators to appear more transparent and trustworthy to potential investors. Presence in the social media gives potential supporters access to user 


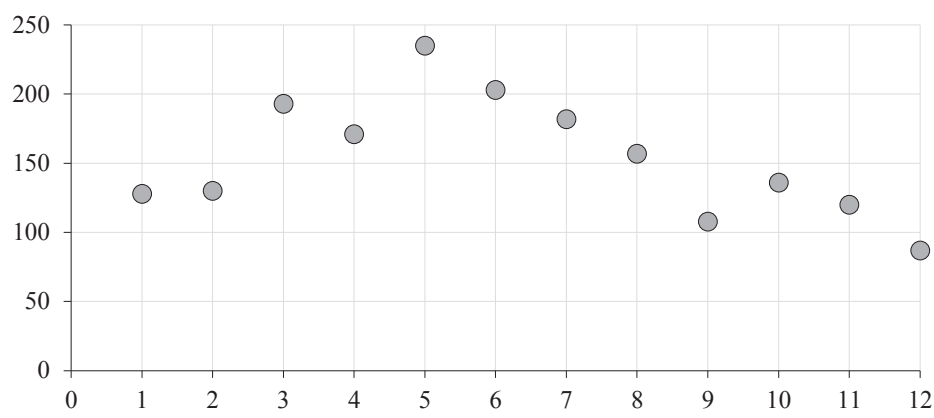

The figure presents data from 2011 till August 2016, the figure does not include projects published on the platform between September and December 2016. However, the trend indicated in the graph could be observed for each year of the analysis.

The numbers on the horizontal axis refer to the months of the year.

Figure 2. Number of crowdfunded projects broken down into months of the year

Source: own elaboration.

comments on the project and initiator. Polakpotrafi, just as most crowdfunding platforms, allows including information on media presence. This was used to count the average number of media notices of the project called up by the project initiator and group them according to categories, to which the project is tied. A decidedly larger media presence was observed in the case of successful projects (2.25 media mentions per successful project as against 1.2 mentions for unsuccessful projects) - Figure 3.

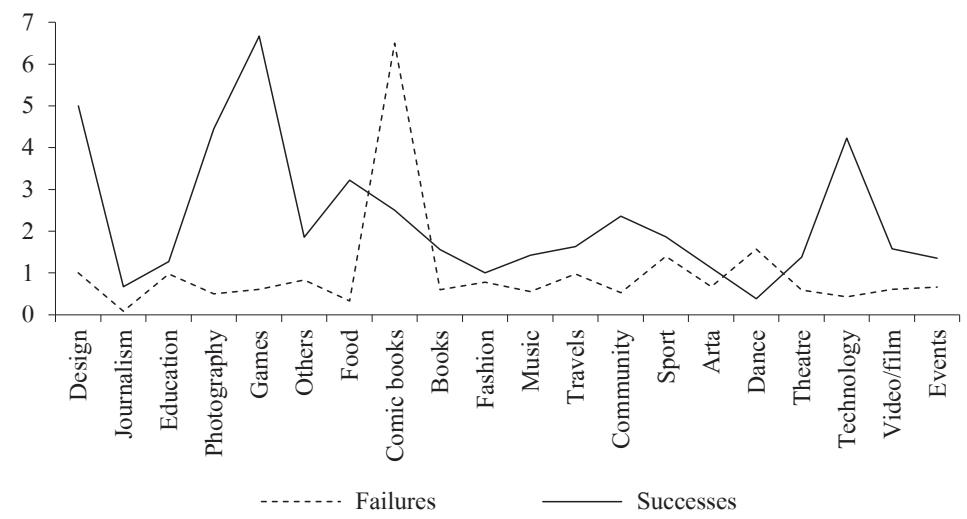

Figure 3. Average number of media notices about crowdfunded projects by categories Source: own elaboration.

For successful projects, the greatest interest was generated by projects in the categories Games ( 7 posts per project on average) and Design ( 5 posts per project). Interestingly, for 
failed projects, the category Comics stands out in terms of the number of comments, with 7 posts per project and only 3 in the same category for failed projects. This might suggest that although a higher success rate is noted for projects with a larger media presence, this may not be the binding rule within each category.

Moreover, it appears that the activity of the project owner and supporters on the platform is an important driver of the project success. In this factor group, two categories were identified: number of project-related news added by the initiator and number of comments added by platform users. The first category contains information on fund-raising progress, project status, project success and media presence. The second category contains posts from platform users, which are usually opinions on the project itself or, less frequently, suggestions and advice on its implementation.

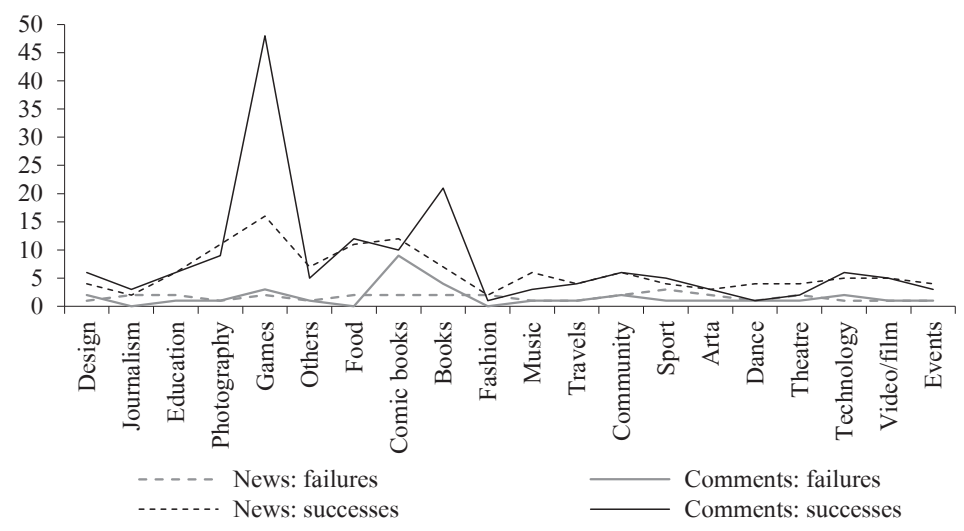

Figure 4. Average number of comments and news related to crowdfunded projects by categories Source: own elaboration.

Higher level of initiator and supporter's activity was observed for projects which turned out to be successful. The average number of news per project was 3.87. For successful projects, this figure reached 6.15 and for unsuccessful ones, only 1.6. The same pattern may be noticed in the activities of people supporting the project. For successful projects, the average number of comments was 7.95 per project, with the same figure at 1.65 for failed projects. The number of supporters was not always the same as the number of comments. The PolakPotrafi platform noted increased activity from supporters in the categories Games (48 comments per project on average), Books (21), Food (12) and Comics (10). Also, in the most active categories, there was a wide discrepancy between success and failure projects. As an example, in the category Games, the number of comments on successful projects was 48 , on average, while the same figure for failed projects was only 3 . The same is true for the category Books (21 against 4 for failures) - Figure 4 . 


\section{Conclusions}

In this article we attempted to identify main characteristics of projects submitted for fundraising on the Polakpotrafi.pl - one of the largest crowdfunding platforms operating in Poland. Since in the empirical literature prevail studies of the US market it is particularly interesting to investigate whether the crowdfunding projects from Poland possess the same attributes. Following other studies we collected a unique dataset of 1,850 projects announced on Polakpotrafi in the years 2011-2016. Among them 957 raised the target amount whereas 893 failed to attract crowd investors.

In general, similarly to the Mollick study (2014) we confirmed uneven geographical dispersion of the crowdfunded projects. The number of projects is highly concentrated among large Polish cities. For instance $38.1 \%$ of projects are initiated from Warsaw, Cracow and Wrocław. Moreover we found that projects from large urban areas have on average higher success rates in comparison to projects submitted from other locations (54\% as compared to $45 \%$ ). These findings suggest the relevance of geographical proximity and imply supporters' preference for projects located close to their place of residence. Moreover it may well be the case that project owners from larger cities are equipped with better qualifications, knowledge and preparedness for a given type of project. This can be also attributed to a wider media presence as well as more effective knowledge spill-over in large urban centers.

Other interesting time patterns in the sample under analysis have been identified. In particular, a definite majority of projects were submitted in the spring and summer months with outstanding number of projects announced in May. Furthermore, the lowest reject rate was observed for projects announced in December, January and February. Since the activity of projects' initiators decreases in these winter months, the level of competition among projects submitted for fundraising is becoming lower.

Similarly to other studies we identified the significance of media presence for the crowdfunded project success. Indeed the average number of posts about the project was twice as large for successful projects. Moreover, the obtained results suggest a positive relation between projects success and the activity of initiators and supporters. In the case of successful projects, the activity was around four times greater than for those that failed to raise pledged amount.

\section{Literature}

Adamska-Mieruszewska, J., Mrzygłód, U. (2014). Wykorzystanie finansowania społecznościowego w Polsce w latach 2011-2014, Zeszyty Naukowe Uniwersytetu Szczecińskiego. Finanse. Rynki finansowe. Ubezpieczenia, 67. AFME (2016). The Shortage of Risk Capital for Europe's High Growth Businesses. Association for Financial Markets in Europe. Retrieved from: www.afme.eu (1.04.2017).

Agrawal, A., Catalini, C., Goldfarb, A. (2015). Crowdfunding: Geography, social networks, and the timing of investment decisions. Journal of Economics \& Management Strategy, 2 (24).

Agrawal, A.K., Catalini, C., Goldfarb, A. (2011). The geography of crowdfunding. National bureau of economic research, Cambridge, No. w16,820. 
Beier, M., Wagner, K. (2015). Crowdfunding Success: A Perspective from Social Media and E-Commerce. Thirty Sixth International Conference on Information Systems, Fort Worth.

Belleflamme, P., Lambert, T., Schwienbacher, A. (2014). Crowdfunding: Tapping the right crowd. Journal of business venturing, 5 (29).

Belleflamme, P., Omrani, N., Peitz, M. (2015). The economics of crowdfunding platforms. Information Economics and Policy, 33.

Cichy, J., Gradoń, W. (2016). Crowdfunding as a Mechanism for Financing Small and Medium-Sized Enterprise. e-Finanse, 3 (12).

Cordova, A., Dolci, J., Gianfrate, G. (2015). The determinants of crowdfunding success: evidence from technology projects. 3rd International Conference on Leadership, Technology and Innovation Management, Procedia - Social and Behavioral Sciences, Vol. 181.

Dziuba, D.T. (2015). Przesłanki badań w zakresie ekonomiki crowdfundingu. Roczniki Kolegium Analiz Ekonomicznych/Szkoła Gtówna Handlowa, 36.

European Commission (2016). Crowdfunding in the EU Capital Markets Union. Commission Staff Working Document, Brussels, 3.5.2016 SWD 154 final.

Koch, J-A., Siering, M. (2015). Crowdfunding success factors: the characteristics of successfully funded projects on crowdfunding platforms. ECIS 2015 Completed Research Papers. Paper 106.

Kozioł-Nadolna, K. (2015). Crowdfunding jako źródło finansowania innowacyjnych projektów. Zeszyty Naukowe Uniwersytetu Szczecińskiego, 854.

Mollick, E. (2014). The dynamics of crowdfunding: An exploratory study. Journal of business venturing, 1 (29).

Šoltés, M., Štofa, T. (2016). Crowdfunding-The Case of Slovakia and the Czech Republic. Quality Innovation Prosperity, 2 (20).

Wieczerzycki, M. (2014). Usługa finansowania społecznościowego - crowdfundingu jako przedmiot współpracy przedsiębiorstw. Studia Oeconomica Posnaniensia, 1 (2).

\section{SUKCESY I PORAŻKI PROJEKTÓW CROWDFUNDINGOWYCH W POLSCE}

Streszczenie: $\mathrm{Cel}$ - W ostatnich latach platformy crowdfundingowe stają się coraz częściej wykorzystywanym narzędziem pomagającym zaprezentować projekt i jednocześnie pozyskać inwestorów. Rosnąca liczba projektów prezentowanych na platformach crowdfundingowych w Polsce skłania do poszukiwania źródeł sukcesu i porażki w pozyskiwaniu inwestorów. Celem artykułu jest przedstawienie najważniejszych charakterystyk projektów prezentowanych na platformie PolakPotrafi.pl, ze szczególnym uwzględnieniem czynników sukcesu i porażki.

Metodologia badania - Badanie zostało przeprowadzone na próbie 1850 projektów prezentowanych na platformie PolakPotrafi.pl w latach 2011-2016. W analizie danych wykorzystano statystyki opisowe.

Wynik - Wskazano najważniejsze tendencje w finansowaniu projektów crowdfundingowych.

Oryginalność/wartość - Do zebrania danych wykorzystano autorski skrypt opracowany w języku Python automatycznie pobierający dane z platformy crowdfundingowej.

Słowa kluczowe: crowdfunding, determinanty sukcesu, badanie empiryczne

\section{Citation}

Adamska-Mieruszewska, J., Mrzygłód, U., Skurczyński, M. (2017). Success and failures of crowdfunded projects in Poland. Finanse, Rynki Finansowe, Ubezpieczenia, 5 (89/2), 415-426. DOI: 10.18276/frfu.2017.89/2-34. 